\title{
Modification of oestrogen-induced uterine hyperaemia by drugs in the ovariectomized rat
}

\author{
S. Phaily and Judith Senior \\ School of Studies in Pharmacology, University of Bradford, Bradford BD7 1DP, U.K.
}

\begin{abstract}
Summary. Uterine blood flow in ovariectomized rats was measured by means of radioactive microspheres. Blood flow was increased from $55 \mathrm{ml} \mathrm{min}^{-1} 100 \mathrm{~g}^{-1}$ by treatment (i.v.) with $0.5 \mu \mathrm{g}$ oestradiol $\mathrm{kg}^{-1}$ and reached $680 \mathrm{ml} \mathrm{min}{ }^{-1} 100 \mathrm{~g}^{-1}$ within $60 \mathrm{~min}$. This oestrogen-induced increase of blood flow was reduced significantly by pretreatment with mepyramine (a histamine $\mathrm{H}_{1}$-receptor antagonist), cellulose sulphate (a kininogendepleting agent) and aprotinin (a kininogenase inhibitor). Cimetidine (a histamine $\mathrm{H}_{2}$ receptor antagonist), kallikrein (kininogenase enzyme) and atropine (an anticholinergic drug) had no effect on the increased uterine blood flow. Indomethacin and AH 7170, which inhibit the formation of prostaglandins, also caused a lower increase in uterine blood flow. None of the pretreatments fully inhibited the oestrogen-induced increase in blood flow, suggesting that more than one mediator may be involved.
\end{abstract}

\section{Introduction}

The stimulatory effect of oestrogen to produce an increase in uterine blood flow and volume has been well documented (Spaziani, 1975). In the rat uterine blood flow rises significantly within $30 \mathrm{~min}$ after an intravenous injection of oestradiol (Spaziani \& Suddick, 1967). This delay in the response has led to the suggestion that oestradiol does not act directly on uterine blood flow but via mediators such as histamine (Spaziani \& Szego, 1959) and prostaglandins (Ryan et al., 1974). Bradykinin, a powerful vasoactive peptide, causes an increase in uterine flow in the sheep when injected into the uterine artery (Killam, Rosenfeld, Battaglia, Makowski \& Meschia, 1973). The kinin precursor, kininogen is present in rat uterine tissue (J. Senior, unpublished observation) and oestrogen-induced hyperaemia in the rat uterus could be mediated through the kinin system.

The present investigation attempts to elucidate the involvement of these local mediators in the increase in blood flow in the uterus of the ovariectomized rat in response to oestrogen.

\section{Materials and Methods}

The animals used were mature virgin female rats (200-250 g) of a CFE-derived strain from colonies bred at the University of Bradford. The animals were ovariectomized bilaterally and were then allowed at least 14 days to recover before being used for experimental procedures. All animals were allowed free access to food and water and were housed in temperature- and light- (07:00-19:00 h) controlled conditions.

\section{Drugs}

Oestradiol (oestra-1,3,5(10)-triene-3,17-diol) (British Drug Houses, Poole, U.K.) was administered in a $10 \%(\mathrm{v} / \mathrm{v})$ solution of propylene glycol. Cellulose sulphate was prepared from Whatman ashless cellulose paper by the method of Astrup, Galsmar \& Volkert (1944) and dissolved in 0.9\% $(w / v) \mathrm{NaCl}$. These drugs were administered intravenously (i.v.) into the tail vein of restrained animals. Indomethacin (Merk, Sharp \& Dohm, Hoddesdon, U.K.) and AH 7170 (2-m(p-chloro-benzoyl) phenyl-propionic acid) (Allen \& Hanbury Research Ltd, Ware, U.K.) were dissolved in $10 \%$ (w/v) 
sodium bicarbonate solution and administered orally. Kallikrein (Bayer AG, Wuppertal, West Germany), mepyramine maleate (May \& Baker Ltd, Dagenham, U.K.) and atropine sulphate (May \& Baker Ltd, Dagenham, U.K.) were dissolved in $0.9 \%(w / v) ~ N a C l$ and administered by the intraperitoneal route (i.p.). Aprotinin (Bayer AG, Wuppertal, West Germany) was dissolved in $0.9 \%(\mathrm{w} / \mathrm{v}) \mathrm{NaCl}$ and given by subcutaneous injection (s.c.). Solutions of cimetidine were prepared by dissolving the base in a small quantity of $0 \cdot 1 \mathrm{~N}-\mathrm{HCl}$, neutralizing by addition of $0 \cdot 1 \mathrm{~N}-\mathrm{NaOH}$ and made up to volume in $0.9 \%(\mathrm{w} / \mathrm{v}) \mathrm{NaCl}$. The drug was administered by i.v. infusion through the jugular vein of conscious rats in which the indwelling cannula had been inserted under ether anaesthesia $24 \mathrm{~h}$ earlier. The drugs were administered in the doses and following the schedules indicated in Table 3.

\section{Measurement of blood flow}

This was measured essentially by the technique described by Rudolph \& Heymann (1967), Neutze, Wyler \& Rudolph (1968), Warren \& Ledingham (1974), Johnston (1975) and Foy \& Lucas (1977). Rats were anaesthetized with $50 \mathrm{mg}$ sodium pentobarbitone $\mathrm{kg}^{-1}$ i.p. Blood pressure was recorded by inserting a cannula into the left femoral artery and connecting the cannula to a pressure transducer and recorder to monitor any pressure changes associated with injection of the microspheres. The right femoral artery was cannulated and connected to a withdrawal pump adjusted for a steady withdrawal rate of $0.5 \mathrm{ml} \mathrm{min}^{-1}$. A cannula was then inserted into the left ventricle via the right common carotid artery. Microspheres with a $15 \mu \mathrm{m}$ mean diameter (Pharmacia) were labelled with scandium-46 and suspended in $0.1 \mathrm{ml}$ Ficoll 70 suspending agent. These labelled microspheres were injected into the left ventricle; approximately 100000 spheres were injected at a steady rate for about $10 \mathrm{sec}$. Blood was withdrawn from the femoral artery starting $5 \mathrm{sec}$ before the injection of the microspheres and continuing until $20-30 \mathrm{sec}$ after the injection. The animals were then killed with an intra-arterial injection of a saturated solution of potassium chloride. Dissection of the tissues took place immediately and the samples were weighed wet. The radioactivity of the tissues and the blood sample was determined with a crystal scintillation counter.

Cardiac output and blood flow to the organs was calculated as follows.

Cardiac output $\left(\mathrm{ml} \mathrm{min} \mathrm{m}^{-1}\right)=\frac{\text { total injected counts } / \mathrm{min}}{\text { blood counts } / \mathrm{min}} \times$ withdrawal speed $\left(\mathrm{ml} \mathrm{min}^{-1}\right)$

Blood flow to organ $\left(\mathrm{ml} \mathrm{min}^{-1}\right)=\frac{\text { organ counts } / \mathrm{min}}{\text { blood counts } / \mathrm{min}} \times$ withdrawal speed $\left(\mathrm{ml} \mathrm{min}^{-1}\right)$

\section{Measurement of prostaglandin- and kinin-like activity in plasma}

Blood samples were taken from ether-anaesthetized rats by cardiac puncture into a heparinized syringe containing $0.05 \mathrm{ml}$ of a solution of the sodium salt of ethylenediaminetetra-aceticacid(EDTA) $\left(0.68 \times 10^{-12} \mathrm{M}\right)$ to act as a kininase inhibitor (Jacobsen, 1966). The samples were centrifuged at $800 \mathrm{~g}$ at $4^{\circ} \mathrm{C}$ and the plasma obtained was assayed for kinin- and prostaglandin-like activity by the cascade superfusion procedure (Naylor, 1977). The tissues used to detect kinin-like activity were kitten rectum and rat duodenum: rat fundus strip and rat colon were used to estimate prostaglandin-like activity. The tissues were superfused at $2 \mathrm{ml} \mathrm{min}^{-1}$ with Krebs' solution at $37^{\circ} \mathrm{C}$ gassed with $95 \% \mathrm{O}_{2}+5 \% \mathrm{CO}_{2}$ (Vane, 1969). The following drugs were added to the Krebs' solution to inhibit interference during the estimations by other endogenous substances in the plasma: $1 \times 10^{-7} \mathrm{~g}$ mepyramine maleate litre $^{-1}$ $\left(\mathrm{H}_{1}\right.$-receptor antagonist), $1 \times 10^{-7} \mathrm{~g}$ hyoscine hydrobromide litre ${ }^{-1}$ (anticholinergic drug), $3 \times 10^{-6} \mathrm{~g}$ propranolol hydrochloride litre ${ }^{-1}\left(\beta\right.$-adrenoceptor antagonist), $1 \times 10^{-7} \mathrm{~g}$ phentolamine mesylate litre ${ }^{-1}\left(\alpha\right.$-adrenoceptor antagonist), $2 \times 10^{-7} \mathrm{~g}$ methisergide litre ${ }^{-1}$ (5-hydroxytryptamine antagonist) and $1 \times 10^{-6} \mathrm{~g}$ indomethacin litre ${ }^{-1}$ (prostaglandin synthesis inhibitor). All concentrations are expressed as base.

\section{Statistical analysis}

The results were assessed by Student's $t$ test; when the samples to be compared had significantly different variances Cochran's modification was applied (Snedecor \& Cochran, 1967). 


\section{Results}

\section{Effect of oestradiol on blood flow}

The dose of $0.5 \mu \mathrm{g}$ oestradiol $\mathrm{kg}^{-1}$ i.v. used throughout was chosen after preliminary experiments because it produced a maximum increase in blood flow through the uterus. There was an increase in uterine blood flow 30 and $60 \mathrm{~min}$ after oestrogen injection (Table 1). The maximum at $60 \mathrm{~min}$ was maintained for about $3 \mathrm{~h}$. Uterine weight was not affected initially, but had increased significantly at $180 \mathrm{~min}(P<0.05)$ when compared to the earlier values. For subsequent experiments the rats were used $60 \mathrm{~min}$ after the treatment with oestradiol. Blood flow to other organs was not significantly affected by the oestradiol treatment (Table 2).

Table. 1. The effect (mean \pm s.e.m.) of $0.5 \mu \mathrm{g}$ oestradiol kg-1 on uterine blood flow in ovariectomized rats at different times after intravenous injection

\begin{tabular}{cccccc}
\hline $\begin{array}{c}\text { Time after } \\
\text { oestradiol (min) }\end{array}$ & $\begin{array}{c}\text { No. of } \\
\text { rats }\end{array}$ & $\begin{array}{c}\text { Uterine } \\
\text { weight }(\mathrm{mg})\end{array}$ & $\begin{array}{c}\text { Cardiac } \\
\text { output } \\
\left(\mathrm{ml} \mathrm{min}^{-1}\right)\end{array}$ & $\begin{array}{c}\text { Uterine } \\
\text { blood flow } \\
\left(\mathrm{ml} \mathrm{min}^{-1}\right. \\
\left.100 \mathrm{~g}^{-1}\right)\end{array}$ & $\begin{array}{c}\% \text { Cardiac } \\
\text { output } \\
\text { to uterus }\end{array}$ \\
\hline 0 & 5 & $90 \pm 3$ & $69 \pm 7$ & $55 \pm 9$ & $0 \cdot 07 \pm 0 \cdot 01$ \\
30 & 5 & $95 \pm 4$ & $62 \pm 4$ & $117 \pm 19^{*}$ & $0 \cdot 17 \pm 0 \cdot 03^{*}$ \\
60 & 20 & $110 \pm 4$ & $66 \pm 2$ & $680 \pm 70^{* *}$ & $1 \cdot 10 \pm 0 \cdot 10^{* *}$ \\
90 & 4 & $100 \pm 4$ & $65 \pm 4$ & $760 \pm 8^{* *}$ & $1 \cdot 14 \pm 0 \cdot 13^{* *}$ \\
120 & 6 & $100 \pm 4$ & $63 \pm 1$ & $817 \pm 68^{* *}$ & $1 \cdot 27 \pm 0 \cdot 10^{* *}$ \\
180 & 4 & $160 \pm 15^{*}$ & $64 \pm 3$ & $566 \pm 45^{* *}$ & $1 \cdot 15 \pm 0 \cdot 07^{* *}$ \\
\hline
\end{tabular}

Values are significantly different from that at $0 \mathrm{~min},{ }^{*} P<0.05 ;{ }^{* *} P<0.001$

Table 2. The effect (mean \pm s.e.m.) of $0.5 \mu \mathrm{g}$ oestradiol $\mathrm{kg}^{-1}$ on blood flow $\left(\mathrm{ml} \mathrm{min}^{-1} 100 \mathrm{~g}^{-1}\right)$ through various tissues of ovariectomized rats $60 \mathrm{~min}$ after intravenous injection

\begin{tabular}{lcccccc}
\hline Treatment & $\begin{array}{c}\text { No. of } \\
\text { rats }\end{array}$ & $\begin{array}{c}\text { Left } \\
\text { kidney }\end{array}$ & $\begin{array}{c}\text { Right } \\
\text { kidney }\end{array}$ & $\begin{array}{c}\text { Small } \\
\text { intestine }\end{array}$ & Brain & Liver \\
\hline $\begin{array}{c}\text { Vehicle only } \\
\text { (controls) }\end{array}$ & 5 & $351 \pm 15$ & $356 \pm 33$ & $54 \pm 5$ & $55 \pm 6$ & $24 \pm 4$ \\
Oestradiol & 20 & $337 \pm 15$ & $340 \pm 13$ & $44 \pm 4$ & $50 \pm 3$ & $17 \pm 2$ \\
\hline
\end{tabular}

\section{Effect of mepyramine, cimetidine and atropine}

Mepyramine produced a significant decrease in the oestrogen-stimulated increase in uterine blood flow (Table 3). Cimetidine infused i.v. did not affect the increase in uterine blood flow induced by oestradiol. Treatment with atropine, an anticholinergic drug, also failed to affect the oestrogenstimulated increase in blood flow.

\section{Effect of cellulose sulphate, aprotinin and kallikrein (Table 3)}

Treatment with cellulose sulphate, a kininogen-depleting agent, significantly decreased the uterine blood flow induced by oestradiol. Aprotinin, the proteinase inhibitor, produced a significant reduction in the oestrogen-induced uterine blood flow. From the results in Table 4 it can be seen that the treatment regimen used for aprotinin did not significantly alter the plasma kinin-like activity. A similar treatment schedule with kallikrein, a kinin-releasing enzyme, did not significantly alter the oestrogen-induced increase in blood flow. 
Table 3. The effect (mean \pm s.e.m.) of pretreatment with drugs on the increase in uterine blood flow at $60 \mathrm{~min}$ after i.v. injection of $0.5 \mu \mathrm{g}$ oestradiol $\mathrm{kg}^{-1}$

\begin{tabular}{|c|c|c|c|c|c|}
\hline \multirow[b]{2}{*}{ Pretreatment $\dagger$} & \multirow{2}{*}{$\begin{array}{l}\text { No. } \\
\text { of } \\
\text { rats }\end{array}$} & \multirow{2}{*}{ 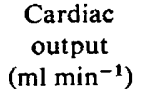 } & \multicolumn{2}{|c|}{ Uterine blood flow } & \multirow{2}{*}{$\begin{array}{l}\% \text { Cardiac } \\
\text { output to } \\
\text { uterus }\end{array}$} \\
\hline & & & $\mathrm{ml} \mathrm{min}-1$ & 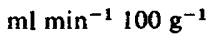 & \\
\hline \multicolumn{6}{|l|}{ None (see Table } \\
\hline $\begin{array}{l}\text { 1), control } \\
\text { Mepyramine maleate }\end{array}$ & 20 & $66 \pm 2$ & $0.77 \pm 0.07$ & $680 \pm 70$ & $1 \cdot 10 \pm 0 \cdot 10$ \\
\hline (5 $\mathrm{mg} \mathrm{kg}^{-1}$ i.p.) & 4 & $66 \pm 2$ & $0.28 \pm 0.05^{* *}$ & $300 \pm 60^{* *}$ & $0.42 \pm 0.08 * *$ \\
\hline \multicolumn{6}{|l|}{ Cimetidine } \\
\hline $\min ^{-1}$ i.v.) & 5 & $60 \pm 1$ & $0.61 \pm 0.05$ & $647 \pm 50$ & $1.00 \pm 0.10$ \\
\hline $\begin{array}{l}\text { Atropine sulphate } \\
\left(5 \mathrm{mg} \cdot \mathrm{kg}^{-1} \text { i.p. }\right)\end{array}$ & 4 & $70 \pm 4$ & $0.64 \pm 0.03$ & $650 \pm 33$ & $0.90 \pm 0.04$ \\
\hline $\begin{array}{l}\text { Cellulose sulphate } \\
\left(1 \mathrm{mg} \mathrm{kg}^{-1} \text { i.v. }\right)\end{array}$ & 7 & $61 \pm 3$ & $0.33 \pm 0.06^{*}$ & $330 \pm 60^{*}$ & $0.55 \pm 0.13^{*}$ \\
\hline $\begin{array}{l}\text { Aprotinin } \\
\left(3 \mathrm{mg} \mathrm{kg}^{-1} \text { s.c., }\right. \\
\text { twice daily for }\end{array}$ & & & & & \\
\hline $\begin{array}{l}2 \text { days }) \\
\text { Kallikrein } \\
\left(30 \mathrm{u} \mathrm{kg}^{-1} \text { i.p., }\right. \\
\text { twice daily for }\end{array}$ & 7 & $66 \pm 2$ & $0.39 \pm 0.05^{*}$ & $360 \pm 60^{*}$ & $0.59 \pm 0.08^{*}$ \\
\hline $\begin{array}{l}2 \text { days }) \\
\text { Indomethacin } \\
\left(1 \mathrm{mg} \mathrm{kg}^{-1} \text { orally, }\right. \\
\text { twice daily for }\end{array}$ & 6 & $67 \pm 2$ & $0.74 \pm 0.06$ & $660 \pm 40$ & $1.08 \pm 0.05$ \\
\hline $\begin{array}{l}2 \text { days }) \\
\text { AH } 7170 \\
\left(1 \mathrm{mg} \mathrm{kg}^{-1} \text { orally, }\right. \\
\text { twice daily for }\end{array}$ & 4 & $62 \pm 1$ & $0.34 \pm 0.02^{*}$ & $320 \pm 20^{*}$ & $0.56 \pm 0.04^{*}$ \\
\hline 2 days) & 6 & $65 \pm 2$ & $0.26 \pm 0.03^{*}$ & $280 \pm 40^{*}$ & $0.45 \pm 0.06^{*}$ \\
\hline
\end{tabular}

Values are significantly different from that for the control group, ${ }^{*} P<0.001 ;{ }^{* *} P<0.005$.

$\uparrow$ The last or only dose of each drug was given $60 \mathrm{~min}$ before the oestradiol injection, except for cimetidine which was infused from $10 \mathrm{~min}$ before to $60 \mathrm{~min}$ after the oestradiol injection.

Table 4. The effect (mean \pm s.e.m.) of aprotinin and $\mathrm{AH} 7170$ (given twice daily for 2 days) on kinin-like and prostaglandin-like activity in the plasma of ovariectomized rats (5/group) killed $2 \mathrm{~h}$ after the last dose

\begin{tabular}{lccc}
\hline & $\begin{array}{c}\text { Saline control } \\
(0.1 \mathrm{ml} \mathrm{s.c.})\end{array}$ & $\begin{array}{c}\text { Aprotinin } \\
\left(3 \mathrm{mg} \mathrm{kg}^{-1} \mathrm{s.c}\right)\end{array}$ & $\begin{array}{c}\text { AH 7170 } \\
\left(1 \mathrm{mg} \mathrm{kg}^{-1} \mathrm{orally}\right)\end{array}$ \\
\hline $\begin{array}{l}\text { Kinin-like material } \\
\begin{array}{l}\text { (as ng bradykinin ml } \\
\text { Prostaglandin-like } \\
\text { material (as ng PGF-2 }\left(\mathrm{ml}^{-1}\right)\end{array}\end{array}$ & $0.54 \pm 0.22$ & $0.72 \pm 0.25$ & $0.63 \pm 0.24$ \\
\hline
\end{tabular}

* Significantly different, $P<0.05$.

\section{Effect of indomethacin and $A H 7170$}

Pretreatment with indomethacin significantly reduced the oestrogen-induced increase in blood flow to the uterus, and similar results were obtained with $\mathrm{AH} 7170$ : the final dose of these drugs was given 60 min before oestradiol was injected. The dose of $\mathrm{AH} 7170$ used has been shown to decrease significantly the prostaglandin-like activity in rat plasma without affecting kinin-like activity (Table 4). 


\section{Effect of the drugs on blood flow through other body organs}

Cardiac output was not affected by any of the drug regimens tested (Table 3 ) and there were few changes in blood flow to other organs. Mepyramine treatment caused an increase in blood flow to the kidneys $\left(403 \pm 25 \mathrm{ml} \mathrm{min}^{-1} 100 \mathrm{~g}^{-1}, n=4\right)$ compared to controls $\left(339 \pm 15 \mathrm{ml} \mathrm{min}^{-1} 100 \mathrm{~g}^{-1}, n=20\right)$ and atropine and cellulose sulphate caused some reduction in blood flow to the small intestine.

\section{Discussion}

The use of radioactive microspheres has been shown to be a suitable technique for the determination of blood flow through the reproductive organs of small animals (Bruce, 1976; Harvey \& Owen, 1976), although it is necessary to anaesthetize the animals. The values for cardiac output and organ blood flow presented in this paper are in agreement with those found in previous studies, and the similarity of blood flow to right and left kidneys indicated a uniform distribution of the microspheres. The results for uterine blood flow in ovariectomized rats obtained by other workers (Bruce, 1976; Harvey \& Owen, 1976) are a little lower than those reported here, but the ranges are similar and the discrepancy may be due to the different microspheres used.

Oestrogens have been shown to increase uterine blood flow in the spayed animal in many species (Spaziani, 1975), and in the present study the increase occurred rapidly up to about 60 min although there was no concomitant increase in uterine weight. The lack of effect of oestrogen on blood flow in the other tissues studied was not unexpected because oestradiol is selectively taken up into the reproductive organs of the rat (Jenson \& Jacobsen, 1962). Histological studies have shown that a general oedema occurs in the uterine tissues within $4-6 \mathrm{~h}$ after oestrogen injection and confirm the increased vascularity at $1 \mathrm{~h}$ (Jailkani \& Talwar, 1975). Oestrogen treatment of ovariectomized rats causes increased synthesis of RNA within $30 \mathrm{~min}$ (Talwar, 1963) and of specific proteins in the uterine cytosol within 30-40 min (Gorski, Noteboom \& Nicolette, 1965). Inhibition of RNA synthesis, however, does not affect the increase in blood flow (Resnick, Battaglia, Makowski \& Meschia, 1975a).

The involvement of histamine as a mediator in the oestrogen-induced hyperaemic response was proposed many years ago by Spaziani \& Szego (1959). The present study has confirmed that histamine may be involved because the antihistamine, mepyramine, in a dose which would normally provide $\mathrm{H}_{1}$-receptor antagonism (Szelenyi \& Thiemer, 1977), produced over $50 \%$ inhibition of the oestrogeninduced increase in blood flow. Changes in organ blood flow in response to $\mathrm{H}_{2}$ receptor stimulation are variable: blood flow increases in the heart and stomach and decreases in brain, liver, kidneys and adrenal glands (Flynn, Johnston \& Owen, 1977). From the results reported here with cimetidine, at a dose level known to produce antagonism of the $\mathrm{H}_{2}$-receptor in the rat (D. Owen, personal communication), it would appear that the $\mathrm{H}_{2}$-receptors are not involved in the oestradiol-induced uterine hyperaemia. Mepyramine, although one of the more specific $\mathbf{H}_{1}$-receptor antagonists, is known to have some anticholinergic activity and so the anticholinergic drug, atropine, was also tested. As in sheep (Resnick et al., 1975b), atropine had no effect on the oestrogen-induced blood flow in the uterus of the rat. This finding suggests that the reduction in blood flow after treatment with mepyramine is not due to any anticholinergic actions of this compound.

The involvement of the kinin-forming system in the uterine blood flow induced by oestrogen has not been previously investigated but bradykinin is known to increase blood flow in the sheep (Resnick et al., 1975b). Because of the short duration of action of bradykinin in the rat it would be difficult to measure the effect of this substance on blood flow by the microsphere technique and the kininogen depleting agent, cellulose sulphate, was investigated instead. Cellulose sulphate does not totally deplete kininogen in rat plasma but the dosage schedule employed is known to result in the maximum depletion of kininogen within $60 \mathrm{~min}$ (McCormick, Senior \& Whalley, 1974). A $50 \%$ reduction in the oestrogen-induced increase of blood flow to the uterus suggests that kinins may be involved in this response. To test this hypothesis further a kininogenase inhibitor, aprotinin, was used to inhibit kinin formation. This treatment resulted in a blood flow in the uterus similar to that obtained with cellulose sulphate, but the results are not definitive as the plasma concentrations of kinin-like material were not affected. Aprotinin is taken up rapidly into certain tissues in the cat (Polansky, Young \& Lefer, 1977) 
and it is possible uterine kininogenase was inhibited but not to an extent which could be reflected in the plasma kinin levels. Treatment with the kinin-releasing enzyme, kallikrein, at a dose which does nor deplete plasma kininogen levels (Senior \& Whalley, 1976), failed to enhance the oestrogen effect on uterine blood flow; this may be due to the pharmacokinetics of the treatment or a maximum response to oestradiol already being achieved by this time after treatment. These results neither confirm nor preclude an involvement of the kinin-forming system in the increase in uterine blood flow induced by oestrogen.

Bradykinin has been reported to release prostaglandins in some smooth muscle tissues (Crocker \& Willavoys, 1976). Although indomethacin inhibits the synthesis of prostaglandins (Vand, 1971), it also has non-specific effects on tissues in vitro (Hargrove, Nesbitt, Gaspar \& Ellis, 1976; Sharma \& Zeitlin, 1977). In the present experiments indomethacin gave a $50 \%$ inhibition of the oestrogeninduced uterine hyperaemia and this result is in agreement with the findings of Ryan et al. (1974) who treated rats subcutaneously with oestradiol benzoate and then measured uterine blood volume by iodinated serum albumin determinations. To test that such results are due to inhibition of prostaglandin synthesis and not to the non-specific actions of indomethacin, a more specific prostaglandin synthesis inhibitor, $\mathrm{AH} 7170$, was used in the present experiments. Treatment with $\mathrm{AH} 7170$, which has a $K_{i}$ value of $4 \times 10^{-7} \mathrm{M}$ (indomethacin $K_{i}$ in the same test, $1.3 \times 10^{-5} \mathrm{M}$ : Allen \& Hanbury Research Ltd), significantly inhibited the oestrogen-induced uterine blood flow, and significantly reduced plasma prostaglandin levels without affecting plasma kinin levels.

It therefore seems possible that all three humoral mediators investigated, histamine, kinins and prostaglandins, may be involved in the oestrogen-induced increase in blood flow in the uterus of the ovariectomized rat. These mediators may be acting synergistically, as in the inflammatory response (Brocklehurst, 1971), to increase uterine blood flow as inhibition by any of the mediatorsalonewas not total. Action through secondary substances such as adenosine or the adenosine nucleotides also seems possible.

Alterations in the components of the kinin-forming system by treatment with cellulose sulphate or aprotinin can cause a prolongation of pregnancy in the rat (McCormick et al., 1974; Senior \& Whalley, 1976). Inhibitors of prostaglandin synthesis also prolong gestation in the rat (Csapo, 1977). The changes in uterine blood flow brought about by these compounds may contribute to this effect on gestation and fetal well-being.

We thank Mr R. Goundry for a supply of healthy animals; Dr E. Philip, Bayer AG for a supply of aprotinin; Dr M. A. Stockham, Allen \& Hanbury Research Ltd, for a supply of AH 7170; Dr J. E. Pike of Upjohn, Kalamazoo, for gifts of prostaglandins; and Dr Barbara J. Clark, Sandoz AG, for the supply of bradykinin.

\section{References}

Astrup, T, Galsmar, B. \& Volkert, M. (1944) Polysaccharide sulfuric acids as anticoagulants. Acta physiol. scand. 8, 215-222.

Brockeehurst, W.E. (1971) Role of kinins and prostaglandins in inflammation. Proc. $R$. Soc. Med. 64, 4-6.

BRUCE, N.W. (1976) The distribution of blood flow to the reproductive organs of rats near term. J. Reprod. Fert. 46, 359-362.

Crocker, A.D. \& Willavoys, S.P. (1976) Possible involvement of prostaglandins in the contractile action of bradykinin on rat terminal ileum. J. Pharm. Pharmac. 28, 78-79.

Csapo, A.I. (1977) Inhibition of prostaglandin synthesis and contractility in the rabbit and rat uterus by ibuprofen. Prostaglandins 13, 735-743.

Flyn,, S.B., Johnston, B.M. \& OWEN, D.A.A. (1977) The cardiovascular response to dimaprit, a selective histamine $\mathrm{H}_{2}$-receptor agonist. Br.J. Pharmac. 61, 101-107.
FoY, J.M. \& LuCAS, P.D. (1977) Effects of experimental diabetes and genetic obesity on regional blood flow in the rat. Diabetes 26, 986-992.

Gorski, J., Noteboom, W.D. \& Nicolette, J.A. (1965) Estrogen control of the synthesis of RNA and protein in the uterus. J. cell. comp. Physiol. 66, Suppl. 1, 91109.

Hargrove, J.L., Nesbitt, D., Gaspar, M.J. \& Ellis, L.C. (1976) Indomethacin induces rat uterine contractions in vitro and alters reactivity to calcium and acetyl choline. Am. J. Obstet. Gynec. 124, 25-29.

Harvey, C.A. \& OWEN, D.A.A. (1976) Changes in uterine and ovarian blood flow during the oestrous cycle in rats. $J$. Endocr. 71, 367-369.

JACOBSEN, S. (1966) Substrates for plasma kinin-forming enzymes in rat and guinea-pig plasma. Br.J. Pharmac. 28, 64-72.

Jailkhani, B.L. \& TalwaR, G.P. (1975) The role of estrogens in differentiation of growth target tissues. 
In Molecular Mechanisms of Gonadal Hormone Action, Vol. 1, pp. 359-395. Eds J. A. Thomas \& R. L. Singhal. H. M. \& M. Medical and Scientific Publishers, Aylesbury.

Jensen, E.V. \& JACOBSon, H.I. (1962) Basic guides to the mechanism of oestrogen action. Recent Prog. Horm. Res. 18, 387-414.

Johnston, B.M. (1975) The use of radioactive microspheres to compare the effects of hydralazine, guanethidine and SKF 24260 on the redistribution of cardiac output in rabbits. Br. J. Pharmac. 55, 393402.

Killam, A.P., Rosenfeld, C.R., Battaglia, F.C., Makowski, E.L. \& Meschia, G. (1973) Effect of oestrogens on the uterine blood flow of oophorectomized ewes. Am. J. Obstet. Gynec. 115, 1045-1062.

McCormick, J.T., Senior, J. \& Whalley, E.T. (1974) Changes in plasma kininogen levels induced by cellulose sulphate during pregnancy in the rat. $B r . J$. Pharmac. 52, 533-537.

NAYLOR, I.L. (1977) A simple and inexpensive piece of apparatus for cascade superfusion procedures. $B r . J$. Pharmac. 59, 529.

Neutze, J.M., Wyler, F. \& Rudol.PH, A.M. (1968) Use of radioactive microspheres to assess distribution of cardiac output in the rabbit. Am.J. Physiol. 215, 486495.

Polansky, E.W., Young, K.R. \& Lefer, A.M. (1977) Tissue uptake of isotopically labelled aprotinin in early myocardial ischemia. Arch. Int. Pharmacodyn. 225, 124-133.

Resnick, R., Battaglia, F.C., Makowski, E.L. \& MEschiA, G. (1975a) The effect of actimomycin D on oestrogen-induced uterine blood flow. Am.J. Obstet. Gynec. 122, 273-277.

Resnick, R., Killam, A.P., Barton, M.D., Battaglia, F.C., Makowski, E.L. \& Meschia, G. (1975b) The effect of various vasoactive compounds upon the uterine vascular bed. Am.J. Obstet. Gynec. 125, 201206.

Rudolph, A.M. \& Heymann, M.A. (1967) The circulation of the foetus in utero: methods for studying distribution of the blood flow. Circulation Res. 21, 163-184.
Ryan, M.J., Clark, K.E., Van Orden, D.E., Farley, D., Edvinsson, L., Sjoberg, N.O., Van Orden, L.S. \& BRODY, M.J. (1974) Role of prostaglandins in estrogen-induced hyperemia. Prostaglandins 5, 257266.

Senior, J. \& Whalley, E.T. (1976) The influence of drugs on the kinin-forming system in relation to pregnancy and parturition in the rat. $J$. Reprod. Fert. 47, 319-323.

Sharma, J.N. \& Zeitlin, 1.J. (1977) Indomethacin in low concentration potentiates the action of some spasmogens on the isolated oestrous rat uterus. J. Pharm. Pharmac. 29, 316-317.

SNEDCoR, G.W. \& CoCHRAN, W.G. (1967) The comparison of two samples. In Statistical Methods, pp. 91119. Iowa State University Press, Ames, lowa.

Spaziani, E. (1975) Accessory reproductive organs in mammals: control of cell and tissue transport by sex hormones. Pharmac. Rev. 27, 207-286.

Spaziani, E. \& Suddick, R.P. (1967) Hexose transport and blood flow rate in the uterus: effects of estradiol, puramycin and actinomycin D. Endocrinology 81, 205-212.

Spaziani, E. \& Szego, C.M. (1959) Further evidence for mediation by histamine of estrogenic stimulation of the rat uterus. Endocrinology 64, 713-723.

Szelenyi, V.I. \& Thiemer, K. (1977) Über die Beteiligung Histamin $\mathrm{H}_{1}$ und $\mathrm{H}_{2}$-Rezeptoren an der durch Histamin ausgelösten Blutdrucksenkung. Arzmeim.Forsch. Drug Res. 27, 809-811.

TALWAR, G.P. (1963) Kinetics of the biochemical changes in the uterus following $17 \beta$ estradiol administration with particular reference to RNA metabolism. Proc. 7th Int. Congr. Planned Parenthood, p. 495. Excerpta Medica Foundation, Amsterdam.

VANE, J.R. (1969) The release and fate of vasoactive hormones in the circulation. Br.J. Pharmac. 35, 209-242.

VANE, J.R. (1971) Inhibition of prostaglandin synthesis as a mechanism of action for aspirin-like drugs. Nature, New Biol. 231, 232.

Warren, D.J. \& Ledingham, J. (1974) Measurement of cardiac output distribution using microspheres. Some practical and theoretical considerations. Cardiovascular Res. 8, 570-581.

Received 28 September 1977 